\title{
ARGININE VASOPRESSIN RESPONSE TO ANAESTHESIA PRODUCED BY HALOTHANE, ENFLURANE AND ISOFLURANE
}

\author{
K.M. LEIGHTON, S.L. LIM AND N. WILSON
}

\begin{abstract}
Some of the effects of inhalational anacsthetics may be mediated by $\beta$-endorphins acting on opioid receptors. Stimulation of such receptors has been shown both to promote and to inhibit the release of arginine vasopressin (AVP). Ten rabbits were studied to determine the response of plasma AVP to a predetermined time/concentration "dose" of halothane, enflurane or isoflurane. Abolition of corneal reflex was used as a standard end-point. Plasma samples were obtained from awake animals and after exposure to the anaesthetics, the sequence being randomly assigned. No significant changes in plasma AVP concentrations were observed when predetermined time/concentration "doses" of the agents were administered to the rabbits. Anaesthesia produced by halothane, enflurane or isoflurane, therefore, is not necessarily accompanied by changes in plasma AVP.
\end{abstract}

KEY WORDS: BRAIN, $\beta$-endorphins, arginine vasopressin; ANAESTHETICS, volatile, halothane, enflurane, isoflurane.

THE RELATIONSHIP between anaesthesia and the release of arginine vasopressin (AVP) is confused. Ishihara, et al. reported that diethyl ether and halothane increased plasma AVP concentration in man. ${ }^{1}$ Philbin and Coggins, however, could find no evidence to support this. ${ }^{2}$

Some explanation for this discord may lie in the clinical setting of the studies and the great variety of stimuli which may lead to the release of AVP. The difficulty of producing standard conditions and, in particular, the problem of defining the depth of anaesthesia may have contributed to the different plasma AVP responses which have been reported. Furthermore, the endocrine response to anaesthetic agents, as far as AVP release is concerned, may be a function of time and dose in addition to other variables.

Accordingly, we determined to measure plasma AVP levels in rabbits before and after the administration of halothane, enflurane or isoflurane. We decided to use abolition of corneal

K.M. Leighton, M.B., F.R.C.P.(C), Professor, Departments of Anaesthesia and Pharmacology; S.L. Lim, B.Sc., Research Associate, Department of Pharmacology; N. Wilson, Ph.D., Associate Professor, Department of Physiology; The University of British Columbia, Vancouver, B.C., V6T IW5, Canada.

Reprint requests to: Dr. Kenneth M. Leighton, Department of Pharmacology, Faculty of Medicine, The University of British Columbia, 2176 Health Sciences Mall, Vancouver, B.C., V6T 1 W5. reflex as our anaesthetic end-point. The concentration/time factor necessary to achieve the abolition of this reflex was predetermined for each rabbit before commencing the experiment. We reasoned that in this way we would avoid the AVP release which might result from corneal stimulation in the unanaesthetized state. Any changes in plasma levels of AVP should, therefore, result solely from the actions of the anaesthetic agents themselves

\section{METHODS}

Ten male rabbits (3-4 kg each) were studied. Plasma AVP measurements were made with the animals awake and during the administration of halothane*, enflurane $\dagger$ or isoflurane $f$. Each rabbit was studied under all circumstances. In each animal at least 48 hours separated each anaesthetic. The sequence of experiments was assigned by random numbers.

\section{Determination of Anaesthetic Dose}

Rabbits were placed in a closed box (Figure I) and allowed to rest quietly for 30 minutes. Oxygen was supplied to the box during this time. The anaesthetic agent was then added to the oxygen and, when the animal appeared to be sleeping, the corneal reflex was tested every 60

* Supplied by Hoechst Pharmaceuticals. †Supplied by Ohio Medical Canada, Inc.

Can. Anaesth. Soc. J., vol. 29, no. 6, November 1982 
sec, using a long glass rod. Anaesthetic vaporiser setting, oxygen flow rate and duration of anaesthetic administration were noted at the point of disappearance of the corneal reflex. This was taken to be the predetermined anaesthetic "time-dose" for each rabbit.

\section{Experimental Observations}

At least one week after the animals had recovered from their first exposure to the anaesthetic, a cannula was inserted into a central ear artery and the rabbit was placed in the box as before. The arterial line was delivered from the box through an airtight seal (Figure 1). Oxygen was administered for 30 minutes with the animal resting quietly. At this point either a blood sample $(6 \mathrm{ml})$ was taken for AVP assay (awake specimen) or the animal was given the predetermined time/concentration dose of the anaesthetic agent. An arterial blood sample was obtained for AVP analysis when the predetermined amount of anaesthetic had been administered. The order of sampling (i.e., "awake", halothane, enflurane, isoflurane) was randomly assigned for each rabbit.

Specimens for AVP assay were immediately centrifuged, the plasma separated and then frozen. Specimens were stored in the frozen state for not longer than three weeks. Radioimmunoassay of AVP was done in the laboratory of one of us (N.W.), employing a modification of the method of Robertson. ${ }^{3}$

The lower limit of assay sensitivity was taken to equal 80 per cent of maximum binding (maximum binding $=$ binding of the iodinated hormone to the antibody in absence of uniodinated hormone) and was $0.225 \pm 0.019$ (SEM, n $=13$ ) pg AVP/tube. Fifty per cent depression of binding was achieved at $0.757 \pm 0.052$ (SEM, $n$ $=13) \mathrm{pg} \mathrm{AVP} /$ tube. $300 \mu \mathrm{l}$ of plasma was used per tube for the measurements of the unknowns. The measurements were done in triplicate and accompanied by triplicate determinations of non-specific binding for each plasma sample. Intra-assay and inter-assay variability were 4.5 and 7.4 per cent respectively.

Although the use of our radioimmunoassay system on dog or human plasma samples requires prior extraction of plasma to remove nonspecific interference, no such interfering factors could be detected in rabbit plasma. In a separate experiment, four rabbits were subjected to haemorrhage to stimulate vasopressin release, and sequential blood samples were collected. RIA measurements showed gradual elevation of the immunoreactive hormone. The highest level

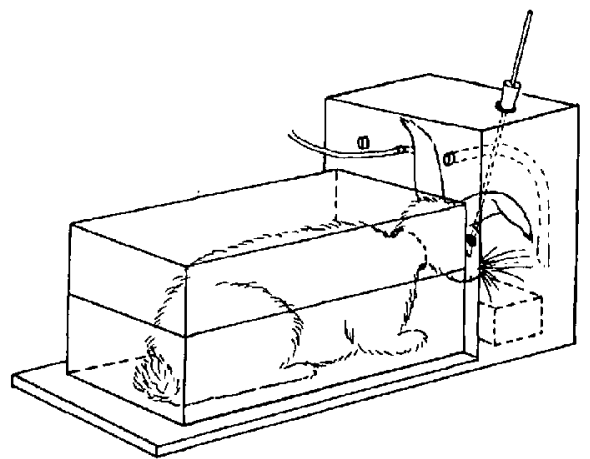

FIGURE 1 Rabbit in gas-tight box. Note glass rod for corneal stimulation.

obtained was $35.0 \pm 3.2 \mathrm{pg} / \mathrm{ml}(\mathrm{M} \pm \mathrm{SE})$ in the fifth $10 \mathrm{ml}$ blood sample (rabbit weight $2.8 \mathrm{~kg}$ ). High vasopressin samples were subjected to the acetone-petroleum ether extraction procedure and subsequently measured by radioimmunoassay. All of the immunoreactivity present in the unextracted samples remained after the extraction procedure. In two experiments the average vasopressin recovered following solvent extraction was 103 and 118 per cent respectively. When unextracted high vasopressin rabbit plasma (5th haemorthage sample) was measured at increasing dilutions, parallelism with AVP standard curve was obtained (Figure 2). We thus conclude that vasopressin in rabbit plasma may be measured without prior solvent extraction using our RIA system and that our assay could detect AVP increase.

In the experimental series, AVP levels in awake animals were compared with those obtained after the administration of the predetermined doses of halothane, enflurane and isoflurane. In addition, the levels of AVP obtained with each anaesthetic were compared.

Data were analysed statistically by a one-way analysis of variance (Duncan's Multple Range Test).

\section{RESULTS}

The results of the AVP assays are shown in Table I.

No statistically significant difference in plasma AVP concentration was demonstrated between awake rabbits and those which had been exposed to halothane, enflurane or isoflurane after the administration of a predetermined dose of the agent. Moreover, no significant difference in plasma AVP was demonstrated between rabbits exposed to each agent. 
TABLE I

arginine Vasopressin Concentration in Rabbit Plasma $(\mathrm{pg} / \mathrm{ml})$

\begin{tabular}{ccccc}
\hline \hline Rabbit & Awake & Isofurane & Halothane & Enflurane \\
\hline 1 & $0.87 \pm 0.07$ & $0.91 \pm 0.06$ & $<0.6$ & $0.99 \pm 0.22$ \\
2 & $0.69 \pm 0.28$ & $0.73 \pm 0.18$ & $0.81 \pm 0.11$ & $7.94 \pm 0.71 \dagger$ \\
3 & $0.96 \pm 0.09$ & $0.78 \pm 0.07$ & $0.98 \pm 0.16$ & $1.03 \pm 0.09$ \\
4 & $<0.6$ & $1.39 \pm 0.50$ & $<0.6$ & $<0.7$ \\
5 & $<0.6$ & $<0.6$ & $<0.6$ & $0.64 \pm 0.12$ \\
6 & $<0.6$ & $<0.6$ & $9.58 \pm 0.81 \dagger$ & $<0.6$ \\
7 & $1.03 \pm 0.34$ & $<0.6$ & $<0.6$ & $<0.6$ \\
$8^{*}$ & $0.61 \pm 0.16$ & $-\overline{00.6}$ & $<0.6$ & $<0.6$ \\
9 & $<0.6$ & $<0.6$ & $<0.6$ & $<0.6$ \\
10 & $0.89 \pm 0.22$ & $0.89 \pm 0.03$ & &
\end{tabular}

*Rabbit died before completion of study.

†Rabbits obviously hypoxic due to airway obstruction by secrections.

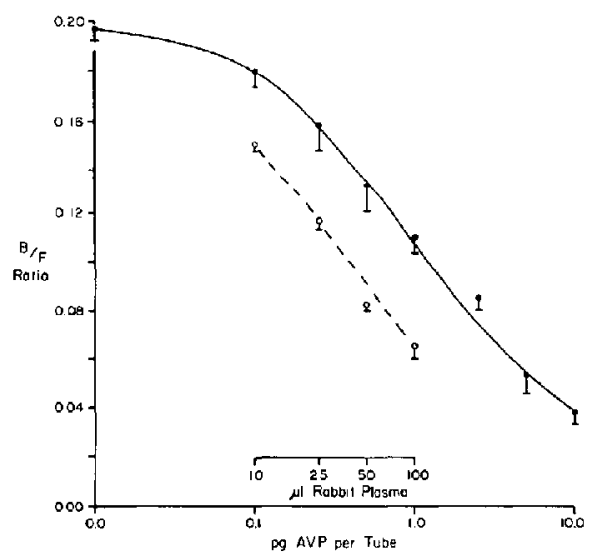

Figure 2 Comparison of increasing volume of rabbit plasma (O---O) (sample obtained after haemorrhage) with the AVP standard curve (- Standard: USP Pit Extr. 2.1 U/ml, standardized against synthetic AVP (Spectrum Labs, Los Angeles, CA, Lot 208062) to express AVP in pg. Monoiodinated AVP ( ${ }^{125}$ I-AVP) prepared from Sigma AVP, Gr. VI; specific activity $\sim 1,000 \mu \mathrm{Ci} / \mu \mathrm{g}$. Nonequilibrium system $\left(4^{\circ} \mathrm{C}\right)$ : three days preincubation plus two days following addition of ${ }^{125} \mathrm{I}-\mathrm{AVP}$. Antibady: GP-15, 1:60,000.

In two rabbits (\#2 and \#6) increased plasma AVP concentrations were recorded during struggling and partial asphyxia

\section{Discussion}

Arginine vasopressin is released from the posterior pituitary gland in response to a variety of stimuli which include the osmolality of extracellular fluid and baroreceptor stimulation. ${ }^{4}$

A reduction in urine output accompanying anaesthesia and surgery was first reported many years ago and it was held that anaesthetic agents were reponsible for this antidiuresis. ${ }^{5}$ With the discovery of the antidiuretic activity of posterior pituitary extract it was believed that some of the drugs used in anaesthetic practice were capable of causing the release of this substance which was later identified as arginine vasopressin (AVP or ADH). In particular, it was held that morphine and perhaps other opioids were powerful in AVP releasing activity. ${ }^{6-8}$

However a number of investigators have thrown some doubt on the concept that either volatile inhalational anaesthetics or opioids do cause AVP release. The introduction of sensitive techniques for AVP measurement by radioimmunoassay has given fresh impetus to this re-evaluation. ${ }^{9}$

In the case of opioids the relationship with the release of AVP is uncertain, as is shown by the work of Aziz, et al. These authors demonstrated that the response of plasma AVP to the intracerebroventricular administration of morphine is both dose and time dependent. Small doses of morphine inhibit and larger doses first stimulate and then subsequently inhibit the release of AVP. ${ }^{10}$

In animals and in man the opioid antagonist naloxone has been reported to antagonize analgesia produced by nitrous oxide and some volatile anaesthetics. ${ }^{11-13}$ It seems possible, therefore, that analgesia produced by nitrous oxide and the other anaesthetic agents may be mediated by the release of $\beta$-endorphins, which then act upon opioid receptors. ${ }^{14}$ Groups of opioid receptors have been identified in the posterior pituitary. ${ }^{15}$

On the basis of the work of Aziz, et al., this pituitary receptor occupancy may be followed by 
changes in plasma AVP concentration and it might be anticipated, therefore, that the administration of anaesthetic amounts of such agents as halothane, enflurane or isoflurane would be accompanied by similar alterations in the concentration of AVP in peripheral plasma if the actions of these agents are indeed mediated in part by $\beta$-endorphins.

Hypoxia and hypercarbia associated with asphyxia, together with excitement, struggling and hypertension, are apparently potent nonosmotic stimuli for the release of vasopressin. That our techniques are capable of detecting such an increased release is evident by the AVP concentrations which we measured in rabbits \#2 (enflurane) and $\# 6$ (halothane) which were underventilating and suffering partial asphyxia (Table I).

With knowledge of the many possible stimuli for AVP release, it is clear that in many of the circumstances of anaesthesia and surgery increased AVP concentrations may be anticipated as a result of influences other than the pharmacological actions of anaesthetic agents.

The results of the present experiments, however, appear to demonstrate that the administration of halothane, enflurane or isoflurane does not cause a rise in plasma AVP in rabbits when abolition of the corneal reflex is the anaesthetic end-point. It is also clear that, under these circumstances, there are no significant differences between the anaesthetics insofar as plasma arginine vasopressin levels are concerned.

\section{REFERENCES}

1. Ishihara, H., Ishida, K., OYama, T., Kudo, T. \& KUDO, M. Effects of general anaesthesia and surgery on renal function and plasma ADH levels. Can. Anaesth. Soc. J. 25: 312-318 (1978)

2. Philbin, D.M. \& Coggins, C.H. The effect of anaesthesia on antidiuretic hormone levels. $I n$ : Stoekel, H. and Oyama, T. eds. Endocrinology in Anaesthesia and Surgery. New York: Springer-Verlag (1980).

3. Robertson, G.L., Mahr, E.A., Athar, S. \& SinHA, T. Development and clinical application of a new method for the radioimmunoassay of arginine vasopressin in human plasma. J. Clin. Invest. 52: 2340-2352 (1973).

4. SChrier, R.W., Bell, T. \& ANDERSON, R.J. Osmotic and non-osmotic control of vasopressin release. Am. J. Physiol. 236: F321-F332 (1979).

5. Pringle, H., Maunsell, R.C. \& Pringle, S. Clinical effects of ether anaesthesia on renal activity. Br. Med. J. 2: 542-543 (1905).

6. HAYs, R.M. \& LEVINE, S.D. Pathophysiology of Water Metabolism. In: Bremmer, B.M. and Rector, F.C. eds. The Kidney. Philadelphia: W.B. Saunders (1976).

7. GuYron, A.C. Textbook of Medical Physiology, 5th ed. Philadelphia: W.B. Saunders (1976).

8. JAFFE, J.H. \& MARTIN, W.R. Narcotic analgesics and antagonists. In: Goodman, L.S. and Gilman, A., eds. The Pharmacological Basis of Therapeutics, 5th ed. New York: MacMillan (1975).

9. Bonjour, J.P. \& Malvin, R.L. Plasma concentrations of ADH in conscious and anaesthetized dogs. Am. J. Physiol. 218: 1128-1132 (1970).

10. AZIZ, L.A. ForsLing, M.L. \& WoOlF, C.J. The effect of intracerebroventricular injections of morphine on vasopressin release in the rat. $J$. Physiol. 311: 401 (1981).

11. Berkowitz, B.A., NGal, S.H. \& Finck, O.D. Nitrous oxide "analgesia": resemblance to opiate action. Science 194: 967-968 (1976).

12. YanG, J.C. Clark, W.C. \& NGal, S.H. Antagonism of nitrous oxide analgesia by naloxone in man. Anesthesiology 52: 414-417 (1980).

13. Chapman, C.R. \& Benedetti, C. Nitrous oxide effects on cerebral evoked potential to pain. Anesthesiology 51:135-138 (1979).

14. Rossier, J., Battenderg, E., Pitrman, Q., Bayon, A., Koda, A., Miller, R., GuilleMIN, R. \& BLOOM, F. Hypothalamic enkcphalin neurones may regulate the neurohypophysis. Nature (London) 277: 653-655 (1979)

15. Simantov, R. \& SNYder, S.H. Opiate receptor binding in the pituitary gland. Brain Res. 124: $178-184(1977)$.

\section{RESUME}

Certains effets de l'anesthésie par inhalation pourraient être obtenus par médiation des $\beta$ endorphines sur les récepteurs opioïdes. Il a déjà êté démontré que la stimulation de ces récepteurs provoque et inhibe la libération de l'arginine-vasopressine (AVP). L'étude a porté sur dix lapins et avait pour but d'évaluer la réponse de l'AVP plasmatique à une exposition prédéterminée d'halothane, d'enflurane ou d'isoflurane. L'abolition du réflexe coméen a été le critère recherché pour l' arrêt de l'expérience. En séquence randomisée, des spécimens de plasma ont été prélevés sur les animaux éveillés et après exposition aux anesthésiques. On n'a observé aucune modification des concentrations plasmatiques d'AVP. L'anesthésie produite par l'halothane, l'enflurane ou l'isoflurane ne s'accompagne donc pas nécessairement de changements d'AVP plasmatique. 